УДК 35.075:352.07: 32.019.52

\title{
Приліпко Сергій,
}

д-р наук держ. упр., доцент,

ORCID iD 0000-0002-6116-328X

E-mail: prylipko@nubip.edu.ua

\section{НОРМАТИВНО-ПРАВОВІ ЗАСАДИ ІНФОРМАЦЙ̆НӦ̈ ВІДКРИТОСТІ ТА КОМУНІКАЦИЙНОЇ ВЗАЄМОДІЇ ОРГАНІВ ПУБЛІЧНОЇ ВЛАДИ З ГРОМАДСЬКІСТЮ}

\author{
https://doi.org/10.32689/2618-0065-2020-4(6)-232-251
}

Анотація. Сучасна концепція публічного управління вимагає від посадових осіб органів публічної влади бути більш чутливими до запитів громадян, ширше залучати інститути громадянського суспільства до прийняття державно-управлінських рішень, здійснювати свою діяльність прозоро та відкрито. Інформування громадськості та комунікаційна взаємодія $\epsilon$ основними інструментами забезпечення відкритості і прозорості діяльності суб'єктів владних відносин. Влада повинна бути зацікавленою у налагодженні комунікаційного зв'язку у різних формах , що сприятиме успішності реалізації задекларованих реформ та підвищення довіри громадян.Встановлено, що інформаційні відносини між суб'єктами публічного управління базуються на принципах відкритості, доступності, достовірності, повноти, правомірності одержання, використання та поширення інформації. В той же час для налагодження двостороннього зв'язку комунікаційна взаємодія у публічному управлінні між представниками влади та громадськості повинна відповідати принципам прозорості, відкритості, чесності, оперативності, адекватності, партнерства, достовірності та підзвітності. В умовах розвитку демократичного суспільства кожен громадянин має право на отримання повноцінної та достовірної інформації про діяльність органів публічної влади, а останні зобов'язані вчасно й у повній мірі ії̈ висвітлювати, ширше залучати громадськість до формування та реалізації державної політики. На основі аналізу нормативно-правового забезпечення визначено, що інформаційнокомунікаційна діяльність регулюється окремими положеннями Конституції України, законів України, постанов Кабінету Міністрів 


\section{Науковий вісник: Державне управління № 4(6)2020}

України та інших нормативно-правових актів. Вони розкривають права та обов'язки органів публічної влади прозоро висвітлювати інформацію та звітуватися про свою діяльність, надавати відповіді на запити, публічно обговорювати проєкти нормативно-правових актів, проводити громадські слухання та враховувати думку громадськості. Встановлено, що кращими формами для комунікаційної взаємодії є: прийом громадян, зустрічі, консультації, круглі столи, семінари, конференції, засідання, зібрання, наради, збори, урочисті події, громадські слухання, публічні дебати, демонстрації, презентації, виставки, брифінги, пресконференції, прес-тури, вхідна та вихідна кореспонденція, повідомлення у ЗМI, соціальних мережах та на веб-сайтах. Зазначено, що залучення програм та проєктів міжнародної технічної допомоги сприяє налагодженню комунікаційної взаємодії між органами публічної влади та представниками інститутів громадянського суспільства, зокрема під час розроблення комунікаційної стратегії.

Ключові слова: публічне управління, нормативно-правове забезпечення, інформаційна відкритість, комунікаційна взаємодія, органи публічної влади, громадськість.

Постановка проблеми. Реалізація державної політики полягає у цілеспрямованому курсі дій органів публічної влади 3 використанням сукупності механізмів, інструментів, важелів і способів для створення, забезпечення, функціонування та розвитку сервісної держави. В основі сервісної концепції держави лежить якісно новий підхід до соціального призначення держави, що характеризується специфічною формою організації публічної влади, спрямованою на пріоритетність надання публічних послуг, i передбачає розвиток мережевих форм управлінської взаємодії, прозорість і відкритість діяльності органів публічної влади, чутливість до запитів громадян, залучення до співпраці неурядових організацій, надання “онлайнових послуг” тощо [1, с. 160-161]. Інформування громадськості $€$ важливим інструментом забезпечення відкритості і прозорості діяльності органів публічної влади, складовою демократичного процесу прийняття управлінських рішень і передумовою реалізації 
права громадян на участь у публічному управлінні. Для цього необхідно докласти певних зусиль для надання суб'єктам доступу до інформації, використовуючи інноваційні методи іï подання, надаючи свободу на одержання, розповсюдження інформації та висловлення власної точки зору [2, с. 6]. Відкритість i прозорість є взаємопов'язаними 3 процесом комунікації. На будь-яке інформаційне повідомлення органів публічної влади завжди спостерігається зворотна реакція 3 боку громадськості, яка за допомогою різних видів і форм комунікації постійно намагається брати участь у формуванні та реалізації державної політики. В умовах проведення реформ громадськість стає важливим суб'єктом публічного управління.

\section{Аналіз останніх досліджень і публікацій. Окремі} питання вдосконалення механізмів інформаційної відкритості та комунікаційної взаємодії органів публічного управління 3 громадськістю висвітлювали у своїх наукових працях такі вчені і практики як К. Алексеєва, Н. Алюшина, О. Антонова, О. Васильєва, В. Гошовська, І. Грищенко, Н. Драгомирецька, В. Дрешпак, А. Дуда, О. Карпенко, I. Корж, В. Куйбіда, Н. Ларіна, О. Петроє, О. Руденко, В. Чмига та ін. У сучасних умовах проведення реформи державного управління процеси активізації громадського сектору та залучення його представників до прийняття управлінських рішень спільно 3 органами публічної влади потребують більш чіткого розуміння ключових аспектів нормативно-правового забезпечення даної проблематики.

Метою статті $\epsilon$ аналіз основних положень законодавчих та нормативно-правових актів держави щодо забезпечення інформаційної відкритості та комунікаційної взаємодії державних органів виконавчої влади та органів місцевого самоврядування з громадськістю.

\section{Виклад основного матеріалу. Інформаційно-} комунікаційна діяльність у публічній сфері держави в умовах розвитку інформаційного суспільства регулюється окремими 
положеннями Конституції України, законів України, постанов Кабінету Міністрів України та інших нормативно-правових актів. Зокрема, Конституція України [3] гарантує кожному громадянину право: вільно збирати, зберігати, використовувати і поширювати інформацію усно, письмово або в інший спосіб; право на свободу думки і слова, на вільне вираження своїх поглядів і переконань; право брати участь в управлінні державними справами; право направляти індивідуальні чи колективні письмові звернення або особисто звертатися до органів державної влади, органів місцевого самоврядування та посадових і службових осіб цих органів, що зобов'язані розглянути звернення i дати обгрунтовану відповідь у встановлений строк. Інші законодавчі та нормативно-правові акти врегульовують права та обов'язки органів публічної влади прозоро висвітлювати інформацію та звітуватися про свою діяльність, надавати відповіді на запити, публічно обговорювати проєкти нормативно-правових актів, проводити громадські слухання та враховувати думку громадськості. Різниця між державним i публічним управлінням полягає саме у залученні представників громадського сектору та інших суб'єктів публічного управління до управління державними справами та прийняття державно-управлінських рішень 3 врахуванням їх пропозицій та зауважень.

Закон України "Про інформацію" [4] регулює між суб' єктами (фізичними та юридичними особами, об'єднаннями громадян і суб'єктами владних повноважень) відносини щодо створення, збирання, одержання, зберігання, використання, поширення, охорони та захисту інформації як об'єкта інформаційних відносин. В Україні державна інформаційна політика здійснюється за такими напрямами: забезпечення доступу кожного до інформації; забезпечення рівних можливостей щодо створення, збирання, одержання, зберігання, використання, поширення, охорони, захисту інформації; створення умов для формування у державі 
Науковий вісник: Державне управління № 4(6)2020

інформаційного суспільства; забезпечення відкритості та прозорості діяльності суб'єктів владних повноважень; створення інформаційних систем і мереж інформації, розвиток електронного урядування; постійне оновлення, збагачення та зберігання національних інформаційних ресурсів; забезпечення інформаційної безпеки; сприяння міжнародній співпраці в інформаційній сфері та входженню до світового інформаційного простору.

Забезпечення інформаційної відкритості та прозорості діяльності органів публічної влади $є$ одним із важливих напрямів державної політики. У ст. 3 зазначається, що інформаційні відносини у державі базуються на принципах іiі відкритості, доступності, достовірності, повноти, правомірності одержання, використання, поширення, зберігання тощо. В умовах розвитку демократичного суспільства кожен громадянин має право на отримання повноцінної та достовірної інформації про діяльність органів публічної влади, а останні зобов'язані вчасно й у повній мірі їі висвітлювати. Публічною $є$ інформація, яка отримана, створена або перебуває у володінні органів державної влади, органів місцевого самоврядування або інших суб'єктів господарювання, які виконують публічні функції [1, с. 137].

Відповідно до Закону України "Про доступ до публічної інформації” [5] така інформація може бути відображеною та задокументованою будь-якими засобами та на будь-яких носіях, отриманою або створеною у процесі виконання суб'єктами владних повноважень своїх обов'язків, передбачених чинним законодавством, або знаходитися у володінні суб'єктів владних повноважень, інших розпорядників публічної інформації. Забезпечення права доступу кожної особи до публічної інформації забезпечується шляхом систематичного й оперативного оприлюднення інформації посадовими особами органів публічної влади в офіційних друкованих виданнях, на офіційних веб-сайтах в мережі Інтернет, на єдиному державному веб-порталі 


\section{Науковий вісник: Державне управління № 4(6)2020}

відкритих даних, на інформаційних стендах або будь-яким іншим способом. У Законі закріплено, що право на доступ до інформації здійснюється на принципах прозорості та відкритості; вільного отримання, поширення та будь-якого іншого використання інформації; рівноправності, незалежно від ознак раси, політичних та інших переконань, статі, етнічного та соціального походження, майнового стану, місця проживання, мовних або інших ознак.

У Законі України “Про державну службу” [6] прозорість ототожнюється із “відкритістю інформації про діяльність державного службовця”. Принцип прозорості є одним із важливих принципів, на основі якого здійснюється державна служба. Державний службовець зобов'язаний надавати публічну інформацію в межах, які визначені у Законі. Керівник органу виконавчої влади кожний рік публічного звітується про діяльність державного органу за участю представників громадських рад, громадських об’єднань, організацій роботодавців, професійних спілок, некомерційних організацій, експертів відповідних галузей та засобів масової інформації. Основна мета проведення щорічного звіту полягає у належному інформуванні громадськості про підсумки діяльності, забезпечення належної прозорості та підзвітності відповідного суб'єкта публічного управління. Інформація про звітування розміщується на офіційному веб-сайті відповідного органу виконавчої влади та у засобах масової інформації не пізніш як за тиждень до проведення публічного звіту та після нього. Публічний звіт діяльності органу виконавчої влади повинен містити інформацію про [7]:

результати роботи із зазначенням виконаних завдань i заходів;

аналіз діяльності із зазначенням показників досягнутих результатів і заходів;

використання коштів державного бюджету;

структуру органу виконавчої влади;

інші питання, які винесені на публічне обговорення. 


\section{Науковий вісник: Державне управління № 4(6)2020}

Типовий порядок проведення публічного звіту керівника органу виконавчої влади встановлює загальні вимоги до організаційних та технічних заходів щодо його підготовки i проведення [7].

Інформаційна відкритість посадових осіб місцевого самоврядування визначається принципами, визначеними [8]. Зокрема, до них належать принципи гласності, підконтрольності, підзвітності, чесності, служіння територіальній громаді та захисту іiі інтересів. Серед основних принципів, які прописані у [9], інформаційну відкритість, на нашу думку, характеризують принципи гласності, підзвітності та відповідальності перед територіальними громадами їх органів та посадових осіб. Зокрема, акти та проєкти актів органів і посадових осіб місцевого самоврядування підлягають обов'язковому оприлюдненню та наданню за запитом відповідно до Закону України "Про доступ до публічної інформації”. У них не може бути обмежено доступ до інформації про витрати чи інше розпорядження бюджетними коштами, володіння, користування чи розпорядження державним чи комунальним майном, у тому числі про умови отримання цих коштів чи майна, прізвища, імена, по батькові фізичних осіб та найменування юридичних осіб, які отримують ці кошти або майно. Нормативно-правові акти набирають чинності з дня їх офіційного оприлюднення, якщо органом чи посадовою особою не встановлено пізніший строк введення цих актів у дію. Ст. 42 Закону України “Про місцеве самоврядування” до повноважень сільського, селищного та міського голови належить оприлюднення затверджених радою програм, бюджетів і звітів про їх виконання. При здійсненні наданих повноважень зазначені посадові особи є підзвітними перед територіальною громадою, тому не рідше одного разу на рік вони звітуються про свою роботу перед територіальною громадою на відкритій зустрічі з громадянами. За вимогою не менше половини депутатів відповідної ради сільський, селищний, міський голова зобов'язаний прозвітуватися перед 
Науковий вісник: Державне управління № 4(6)2020

радою про роботу виконавчих органів у будь-який визначений ними термін. Сесії місцевих рад проводяться гласно із забезпеченням права кожного бути присутніми на них, крім випадків, передбачених законодавством. Протоколи сесій $\epsilon$ відкритими та оприлюднюються і надаються на запит. За оприлюднення проєктів рішень та рішень місцевої ради відповідає секретар.

Збором, аналізом, обробкою та оперативним наданням інформації для ЗМІ про діяльність органів публічної влади займаються інформаційні служби, які функціонують у їх структурі. До них належать інформаційні управління, інформаційно-аналітичні підрозділи, прес-служби, пресцентри, управління і центри громадських зав’язків, прес-бюро, прес-секретарі та прес-аташе 3 відповідним апаратом. Відповідно до ст. 6 Закону України “Про порядок висвітлення діяльності органів державної влади та органів місцевого самоврядування в Україні засобами масової інформаціі” [10] формами підготовки та оприлюднення інформації є:

випуск і поширення бюлетенів (спеціальних бюлетенів), прес-релізів, оглядів, інформаційних збірників, експресінформації тощо;

проведення прес-конференцій, брифінгів, організація інтерв'ю 3 керівниками органів державної влади та органів місцевого самоврядування для працівників вітчизняних i зарубіжних засобів масової інформації;

підготовка і проведення теле- і радіопередач;

забезпечення публікацій (виступів) у засобах масової інформації керівників або інших відповідальних працівників органів державної влади та органів місцевого самоврядування;

створення архівів інформації про діяльність органів державної влади та органів місцевого самоврядування;

інші форми поширення офіційної інформації, що не суперечать законодавству України.

Одним iз ефективних способів оприлюднення різноманітної інформації є їі подання та постійне оновлення на 
інформаційних стендах, які встановлюються у структурних підрозділах органів публічної влади. На інформаційних стендах доцільно розміщувати [11, с. 47]:

інформацію про діяльність органів публічної влади, контактні телефони посадових осіб та структурних підрозділів;

графіки прийому громадян посадовими особами, засідань комісій та інших колегіальних органів;

форми заяв, звернень та роз'яснення;

інформаційні повідомлення (оголошення, анонси);

статистичну інформацію;

проєкти регуляторних та інших нормативно-правових актів, що винесені на публічне обговорення, а також копії окремих нормативно-правових актів та рішень;

інші інформаційні матеріали.

В умовах розвитку діджиталізації вебсайти органів публічної влади стають надійними порталами для розміщення необхідної інформації. Згідно до міжнародних зобов'язань України та у відповідності до демократичних перетворень прийнято ряд нормативно-правових актів, які регулюють питання їх створення та функціонування. Отримана від публічних органів влади своєчасна, оперативна, повна та достовірна інформація $є$ запорукою успішної взаємодії громадян та вирішення актуальних питань на різних рівнях. Одним $з$ показників інформаційної відкритості влади, що піддається чіткому кількісному аналізу, $є$ висвітлення державними органами влади власної діяльності у мережі Інтернет. Визначено 20 видів обов'язкової інформації, що має бути розміщена на сайтах центральних органів виконавчої влади та 26 видів, що повинні бути на сайтах органів місцевої влади [12, с. 13].

Комунікація - це процес інформування, оприлюднення та обміну інформацією, слухання, взяття до уваги почутого, організації i функціонування дієвого зворотного зв'язку, взаємозацікавленої взаємодії з усіма цільовими аудиторіями $[13$, с. 92]. Відкритість влади не $є$ ціллю, але певним 


\section{Науковий вісник: Державне управління № 4(6)2020}

інструментом для забезпечення зворотного зв'язку та підтримки від громадян. В умовах розвиненого суспільства влада сама зацікавлена у наявності такого зворотного зв'язку у формі довіри та підтримки громадянами обраного курсу. Громадськість не може існувати без відкритого доступу до інформації щодо діяльності органів публічної влади. Повинен існувати двосторонній взаємозв'язок між органами публічної влади, $з$ одного боку, та громадянами - 3 іншого [14, с. 9, 20]. Зворотній зв'язок у комунікації підтверджує факт передачі повідомлення від отримувача до одержувача, дозволяє уточнити інформацію та миттєво реагувати на їі зміст. Завдяки цьому можна забезпечити ряд позитивних зрушень у системі державного управління певної країни, які у перспективі ведуть до соціальної згоди та підвищення довіри до влади. Вважаємо, що для налагодження двостороннього зв'язку комунікаційна взаємодія у публічному управлінні між представниками влади та громадськості повинна формуватися на принципах прозорості, відкритості, чесності, оперативності, інформаційної адекватності, партнерства, достовірності та підзвітності.

Питання практичної реалізації громадянами права вносити в органи державної влади пропозиції про поліпшення їх діяльності, викривати недоліки в роботі, оскаржувати дії посадових осіб та державних органів регулює [15]. Реалізація його положень забезпечує громадянам України можливості участі в управлінні державними справами, впливу на поліпшення роботи органів державної влади та органів місцевого самоврядування, відстоювання своїх прав і законних інтересів та їх відновлення у разі порушення.

Взаємовідносини громадських об'єднань 3 органами державної влади та органами місцевого самоврядування врегульовані [16]. Їм надається право брати участь у законотворчій діяльності, створювати при органах державної влади та органах місцевого самоврядування консультативні, дорадчі та інші допоміжні органи для висловлення своєї думки 
щодо важливих питань державного і суспільного значення, проводити консультації та розробляти рекомендації відповідно до сфери їх діяльності, відстоювати законні інтереси своїх представників. Таким чином, для здійснення та захисту прав i свобод, задоволення економічних, соціальних, культурних, екологічних та інших інтересів добровільне об'єднання фізичних осіб та/або юридичних осіб приватного права створюється у форматі громадських організацій та спілок.

Участь громадських об'єднань у здійсненні державної регуляторної політики здійснюється відповідно до положень [17]. У ньому зазначається, що одним із принципів державної політики $є$ врахування регуляторними органами громадської думки на всіх етапах регуляторної діяльності, що може здійснюватися шляхом проведення громадських слухань або інших відкритих форм обговорення, надання фізичними й юридичними особами або їх об'єднаннями ініціатив, пропозицій і зауважень.

Залучення громадян до участі в управлінні державними справами, надання можливості для їх вільного доступу до інформації про діяльність органів виконавчої влади, а також забезпечення гласності, відкритості та прозорості діяльності зазначених органів, здійснюється відповідно до Порядку [18], що визначає основні вимоги до організації і проведення органами виконавчої влади консультацій 3 громадськістю. Консультації з громадськістю проводяться у формі публічного громадського обговорення, електронних консультацій 3 громадськістю та вивчення громадської думки. Визначена форма комунікації сприяє налагодженню системного діалогу органів виконавчої влади з громадськістю, підвищенню якості підготовки рішень 3 важливих питань державного i суспільного життя 3 урахуванням громадської думки, створенню умов для участі громадян у розробленні проєктів рішень. Пропозиції громадськості враховуються державними органами виконавчої влади під час прийняття рішень у публічному управлінні. Інформація, пов'язана з організацією 


\section{Науковий вісник: Державне управління № 4(6)2020}

та проведенням консультацій 3 громадськістю, оприлюднюється у спеціально створеній рубриці “Консультації з громадськістю" офіційного вебсайту органу виконавчої влади. Цією постановою також затверджено типове положення про громадську раду при органах виконавчої влади. До іiі складу на дворічний термін роботи можуть обиратися представники інститутів громадянського суспільства, а саме: громадських об'єднань, релігійних, благодійних організацій, творчих спілок, професійних спілок та їх об’єднань, асоціацій, організацій роботодавців та їх об'єднань, недержавних засобів масової інформації. Вони повинні бути зареєстрованими в установленому порядку і провадити діяльність на території України. Участь представників громадських об’єднань у діяльності громадських рад дає підстави стверджувати про те, що вони виступають не лише об'єктом адміністративноправового регулювання, а через відповідні правовідносини взаємодіють з органами публічної влади та впливають на їх діяльність [19, с. 36].

Інститути громадянського суспільства можуть не лише бути ініціаторами та учасниками громадських слухань, а й сприяти проведенню громадської експертизи відповідно до [20]. Даним нормативно-правовим актом встановлено загальні засади щодо сприяння проведенню інститутами громадянського суспільства та громадськими радами громадської експертизи діяльності центральних і місцевих органів виконавчої влади, яка $\epsilon$ складовою механізму демократичного управління державною та полягає у оцінці діяльності органів публічної влади, ефективності прийняття i виконання управлінських рішень, підготовку пропозицій щодо розв'язання суспільно значущих проблем для їх врахування органами виконавчої влади.

Важливу роль у сприянні комунікаційної взаємодії органів публічної влади 3 громадськістю відіграють програми та проєкти міжнародної технічної допомоги. У результаті реалізації Програми для України 3 розширення прав i 
можливостей на місцевому рівні, підзвітності та розвитку "ULEAD” 3 Свропою” протягом 2016-2020 pp. за підтримки Свропейського Союзу та його 5 країн-членів проведено ряд комунікаційних заходів з підвищення обізнаності про переваги децентралізації та можливості залучення громадян до місцевого самоврядування. Зокрема, проведено загальнонаціональну кампанію “Я громада", яка спрямована на прискорення об’єднання громад та сприяння позитивному ставленню до децентралізації. Кампанією було охоплено 20 областей пересувною виставкою, яка відвідала 39 районів без ОТГ та залучила 6 тис. осіб до проведення публічних заходів 3 комунікаційної взаємодії, а також 500 тис. громадян через соціальні мережі. Завдяки Програмі налагоджено співпрацю 3 близько 30 організаціями громадянського суспільства, які працюють над залученням громадян 3 усієї України. За підтримки U-LEAD було проведено майже 1200 комунікаційних заходів для обговорення інвестиційних стратегій, впровадження велосипедних маршрутів, розробки політики для молоді та людей з інвалідністю, а також реформи у сферах охорони здоров'я та освіти [21].

Швейцарсько-український проєкт "Підтримка децентралізації в Україні” DESPRO - проєкт міжнародної технічної допомоги, що працює у сфері реформи місцевого самоврядування в Україні з 2007 року. Проєкт фінансується Швейцарською Конфедерацією через Швейцарську агенцію розвитку та співробітництва та впроваджується Швейцарським Центром ресурсів та консультацій з питань розвитку. Проєкт надає підтримку в організації та проведенні навчальних тренінгів для представників об'єднаних територіальних громад у розробці місцевих стратегій розвитку, зокрема комунікаційних стратегій діяльності органів місцевого самоврядування. Для розробки стратегії кожна ОТГ створює Комітет зі стратегічного планування та затверджує його склад, до якого входять представники місцевої влади та громадськості - місцеві лідери, вчителі, кращі учні шкіл, 
бізнесмени. Експертні групи працюють з Комітетами лише як тренери та наставники, які пояснюють загальні процеси підготовки стратегій розвитку, алгоритми дій, етапи підготовки стратегій, а також коригують роботу Комітетів за потреби. Завдання експертів полягає у поясненні механізму та передачі усіх засобів для підготовки стратегічного документу громади [22].

Висновки та напрями подальших досліджень. Підсумовуючи вищезазначене, можемо стверджувати, що 3 однієї сторони, для прийняття виважених державноуправлінських рішень представники органів державної влади та органів місцевого самоврядування повинні тісно співпрацювати 3 громадськістю шляхом налагодження ефективної комунікації, демонструючи при цьому інформаційну відкритість і прозорість своєї діяльності. 3 іншої сторони, аналіз законодавчих та нормативно-правових актів 3 питань забезпечення інформаційної відкритості, прозорості та комунікаційної взаємодії показує, що громадськості надається широке коло прав, свобод та різних інструментів для контролю за діяльністю органів публічної влади та забезпечення участі в управлінні державними справами. Залучення програм та проєктів міжнародної технічної допомоги сприяє налагодженню комунікаційної взаємодії між органами публічної влади та громадськості. Вона може бути ефективною лише тоді, якщо у процесі їі здійснення досягається поставлена мета. Вважаємо, що найкращими формами комунікаційної взаємодії між зазначеними суб'єктами публічного управління $є$ : прийом громадян, зустрічі, консультації, круглі столи, семінари, конференції, засідання, наради, збори, урочисті події, громадські слухання, публічні дебати, демонстрації, презентації, виставки, брифінги, прес-конференції, прес-тури, реакція на вхідна та вихідна кореспонденція, повідомлення у ЗМI, соціальних мережах, на веб-сайтах. 


\section{Список використаних джерел}

1. Публічне управління : термін. словн. / уклад. : В. С. Куйбіда та ін. Київ : НАДУ, 2018. 224 с.

2. Державно-громадянська комунікація: шлях від кризи до взаємодії : монографія / В. М. Козаков та ін. Київ: ДП "Вид. дім “Персонал”, 2017. 288 с.

3. Конституція України : Закон України від 28.06.1996 р. (зі змінами) // База даних «Законодавство України» / ВР України. URL : https://zakon.rada.gov.ua/laws/show/254\%D0\%BA/96\% D0\% B2\%D1\%80\#Text (дата звернення 20.10.2020).

4. Про інформацію : Закон України від 02.10.1992 р. № 2657-XXI (зі змінами) // База даних «Законодавство України» / ВР України. URL : https://zakon.rada.gov.ua/laws/show/2657-12\#Text (дата звернення 20.10.2020).

5. Про доступ до публічної інформації: Закон України від 13.01.2011 p. № 2939-VI (зі змінами) // База даних «Законодавство України» / BP України. URL : https://zakon.rada.gov.ua/laws/show/293917\#Техt (дата звернення 20.10.2020).

6. Про державну службу: Закон України від 10.12.2015 р. № 889-VIII (зі змінами) // База даних «Законодавство України» / ВР України. URL : https://zakon.rada.gov.ua/laws/show/889-19\#Text (дата звернення 20.10.2020).

7. Про затвердження Типового порядку проведення публічного звіту керівника органу виконавчої влади: наказ Національного агентство України з питань державної служби від 20.12. 2016 № 277// База даних «Законодавство України» / BP України . URL : https://zakon.rada.gov.ua/laws/show/z0028-17\#Text (дата звернення 20.10.2020).

8. Про службу в органах місцевого самоврядування: Закон України від 07.06.2001 p. 2493-III (зі змінами) // База даних «Законодавство України» / BP України. URL : https://zakon.rada.gov.ua/laws/show/2493-14\#Text (дата звернення 20.10.2020).

9. Про місцеве самоврядування: Закон України від 21.05.1997 р. № 280/97-ВР (зі змінами) // База даних «Законодавство України» / BP України . URL : https://zakon.rada.gov.ua/laws/show/280/97\%D0\% B2\%D1\%80\#Tехt (дата звернення 20.10.2020).

10. Про порядок висвітлення діяльності органів державної влади та органів місцевого самоврядування в Україні засобами масової інформації: Закон України від 23.09.1997 р. № 539/97-ВР (зі змінами) // База даних «Законодавство України» / ВР України. 
URL https://zakon.rada.gov.ua/laws/show/539/97\%D0\%B2\%D1\%80\#Text (дата звернення 20.10.2020).

11. Рубановський К., Федорович О., Дуда А., Федорович О. Інформаційна відкритість органів місцевого самоврядування : посібник для муніципальних посадовців. ГО “Агенство 3 розвитку приватної ініціативи”. Івано-Франківськ, 2009. 96 с.

12. Корж I. Ф. Веб-сайти органів державної влади та органів місцевого саморядування: механізми доступу до публічної інформації. Інформація і право. 2018. № 2(25). С. 9-16.

13. Лідерство в місцевому самоврядуванні : словник термінів / за заг. ред. В. А. Гошовської та ін. Х. : Фактор, 2015. 156 с.

14. Алексеєва К. А., Грищенко I. М. Удосконалення процесу інформаційної відкритості органів публічної влади шляхом практичної реалізації концепції електронного урядування. Науковий вісник: державне управління: журнал. 2020. № 3 (5) 2020. C. 9-21.

15. Про звернення громадян: Закон України від 02.10.1996 р. № 393/96-ВР (зі змінами) // База даних «Законодавство України» / BP України. URL : https://zakon.rada.gov.ua/laws/show/393/96\%D0\%B2\%D1\%80\#Text (дата звернення 20.10.2020).

16. Про громадські об'єднання: Закон України від 22.03.2012 p. № 4572-VI (зі змінами) // База даних «Законодавство України» / BP України. URL : https://zakon.rada.gov.ua/laws/show/457217\#Техt (дата звернення 20.10.2020).

17. Про засади державної регуляторної політики у сфері господарської діяльності : Закон України від 11.09.2003 р. № 1160-IV (зі змінами) // База даних «Законодавство України» / ВР України . URL : https://zakon.rada.gov.ua/laws/show/1160-15\#Text (дата звернення 20.10.2020)

18. Про забезпечення участі громадськості у формуванні та реалізації державної політики: постанова Кабінету Міністрів України від 03.11.2010 p. № 996 (зі змінами). URL : https://zakon.rada.gov.ua/laws/show/996-2010-\%D0\%BF\#Text (дата звернення 20.10.2020).

19. Віхляєв М. Ю. Громадські ради при органах виконавчої влади України та роль громадських об'єднань у їх діяльності. Наук. вісн. Нач. акад. внутр. справ. 2013. № 2. С. 36-43.

20. Про затвердження Порядку сприяння проведенню громадської експертизи діяльності органів виконавчої влади: постанова Кабінету Міністрів України від 05.11.2008 р. № 976 (зі змінами) // База даних «Законодавство України» / ВP України. URL : https://zakon.rada.gov.ua/laws/show/976-2008-\%D0\%BF\#Text (дата звернення 20.10.2020). 


\section{Науковий вісник: Державне управління № 4(6)2020}

21. Внески програми "U-LEAD 3 Свропою" у створення багаторівневої системи управління, яка $\epsilon$ прозорою, підзвітною та реагує на потреби громадян України (станом на серпень 2020 р.) / Децентралізація.

URL : https://donors.decentralization.gov.ua/project/u-lead (дата звернення 20.10.2020).

22. Стратегічне планування розвитку об'єднаних територіальних громад / Швейцарсько-український проект підтримки децентралізації DESPRO. URL: https://despro.org.ua/socialprojects/mistsevi-strategiyi-rozvytku-sela/ (дата звернення 20.10.2020).

\section{References}

1. Kuibida, V. S., Bilynska, M. M., Petroie O. M. \& et al. (2018). Publichne upravlinnia : terminol. slov. [Public administration: terminological dictionary]. Kyiv : NADU [in Ukrainian].

2. Kozakov, V. M., Rashkovska, O. V., Rebkalo, V. A., Romanenko, Ye. O., Chaplai, I. V. (2017). Derzhavno-hromadianska komunikatsiia: shliakh vid kryzy do vzaiemodii: monohrafiia [State-public communication: the path from crisis to interaction: a monograph]. Kyiv: DP "Vyd. dim "Personal" [in Ukrainian].

3. Konstytutsiia Ukrainy vid 28.06.1996 [Constitution of Ukraine as of 28.06.1996]. zakon.rada.gov.ua Retrieved from https://zakon.rada.gov.ua/ [in Ukrainian].

4. Zakon Ukrainy "Pro infornatsiu" vid 02.10.1992 p. No 2657-XXI [The Law of Ukraine "On information" as of 02.10.1992 p. No 2657XXI]. zakon.rada.gov.ua URL : https://zakon.rada.gov.ua/ [in Ukrainian].

5. Zakon Ukrainy "Pro dustup do publichnoi informatsii" vid 13.01.2011 No 2939-VI [The Law of Ukraine "On access to public information" as of 13.01.2011 No 2939-VI]. zakon.rada.gov.ua URL : https://zakon.rada.gov.ua/ [in Ukrainian].

6. Zakon Ukrainy "Pro derzhavnu sluzhbu" vid 10.12.2015 p. No 889VIII [The Law of Ukraine "On public service" as of 10.12.2015 p. No 889-VIII]. zakon.rada.gov.ua URL : https://zakon.rada.gov.ua/ [in Ukrainian].

7. Nakaz Natsionalnoho ahentstvo Ukrainy z pytan derzhavnoi sluzhby "Pro zatverdzhennia Typovoho poriadku provedennia publichnoho zvitu kerivnyka orhanu vykonavchoi vlady" vid 20.12. 2016 No 277. [The Order of National Agency of Ukraine for Civil Service Affairs "On approval of the Standard procedure for conducting a public report of the head of the executive body" as of 20.12. 2016 No 277]. zakon.rada.gov.ua URL : https://zakon.rada.gov.ua/ [in Ukrainian]. 


\section{Науковий вісник: Державне управління № 4(6)2020}

8. Zakon Ukrainy "Pro sluzhbu v orhanakh mistsevoho samovriaduvannia" vid 07.06.2001 No 2493-III [The Law of Ukraine "On service in local governments" as of 07.06.2001 No 2493-III]. zakon.rada.gov.ua URL : https://zakon.rada.gov.ua/ [in Ukrainian].

9. Zakon Ukrainy "Pro mistseve samovriaduvannia" vid 21.05.1997 No 280/97-BP [The Law of Ukraine "On local self-government" as of 21.05.1997 No 280/97-BP]. zakon.rada.gov.ua URL : https://zakon.rada.gov.ua/ [in Ukrainian].

10. Zakon Ukrainy "Pro poriadok vysvitlennia diialnosti orhaniv derzhavnoi vlady ta orhaniv mistsevoho samovriaduvannia v Ukraini zasobamy masovoi informatsii" vid 23.09.1997 No 539/97-BP [The Law of Ukraine "On order of coverage of activity of public authorities and local governments in Ukraine by mass media" as of 23.09.1997 No 539/97-BP]. zakon.rada.gov.ua URL : https://zakon.rada.gov.ua/ [in Ukrainian].

11. Rubanovskyi, K., Fedorovych, O., \& Duda A. (2009). Informatsiina vidkrytist orhaniv mistsevoho samovriaduvannia : posibnyk dlia munitsypalnykh posadovtsiv. Ivano-Frankivsk: HO "Ahenstvo z rozvytku pryvatnoi initsiatyvy" [in Ukrainian].

12. Korzh, I. F. (2018). Veb-saity orhaniv derzhavnoi vlady ta orhaniv mistsevoho samoriaduvannia: mekhanizmy dostupu do publichnoi informatsii [Websites of public authorities and local governments: mechanisms of access to public information]. Informatsiia $i$ pravo Information and Law, 2(25), 9-16 [in Ukrainian].

13. Hoshovska, V. A., Pashko, L. A., \& Huka A. K. (2015). Liderstvo v mistsevomu samovriaduvanni : slovnyk terminiv [Leadership in local self-government: a glossary of terms]. Kharkov: Faktor [in Ukrainian].

14. Alekseieva K. A., Hryshchenko I. M. (2020). Udoskonalennia protsesu informatsiinoi vidkrytosti orhaniv publichnoi vlady shliakhom praktychnoi realizatsii kontseptsii elektronnoho uriaduvannia [Improving the process of information openness of public authorities through the practical implementation of the concept of e-government]. Naukovyi visnyk: derzhavne upravlinnia: zhurnal Scientific Bulletin: Public Administration: Journal, 3 (5), 9-21[in Ukrainian].

15. Zakon Ukrainy "Pro zvernennia hromadian" vid 02.10.1996 No 393/96-BP [The Law of Ukraine "On citizens' appeals" as of 02.10.1996 No 393/96-BP]. zakon.rada.gov.ua URL : https://zakon.rada.gov.ua/ [in Ukrainian].

16. Zakon Ukrainy "Pro hromadski obiednannia" vid 22.03.2012 No 4572-VI [The Law of Ukraine "On public associations" as of 22.03.2012 No 4572-VI]. zakon.rada.gov.ua URL : https://zakon.rada.gov.ua/ [in Ukrainian].

17. Zakon Ukrainy "Pro zasady derzhavnoi rehuliatornoi polityky u sferi hospodarskoi diialnosti" vid 11.09.2003 No 1160-IV [The Law of 
Науковий вісник: Державне управління № 4(6)2020

Ukraine "On the principles of state regulatory policy in the field of economic activity" as of 11.09.2003 No 1160-IV]. zakon.rada.gov.ua URL : https://zakon.rada.gov.ua/ [in Ukrainian].

18. Postanova Kabinetu Ministriv Ukrainy "Pro zabezpechennia uchasti hromadskosti u formuvanni ta realizatsii derzhavnoi polityky" vid 03.11.2010 p. No 996 [Resolution of the Cabinet of Ministers of Ukraine "On ensuring public participation in the formation and implementation of public policy" as of 03.11.2010 p. No 996]. zakon.rada.gov.ua URL : https://zakon.rada.gov.ua/ [in Ukrainian].

19. Vikhliaiev, M. Yu. (2013). Hromadski rady pry orhanakh vykonavchoi vlady Ukrainy ta rol hromadskykh obiednan u yikh diialnosti [Public councils under the executive authorities of Ukraine and the role of public associations in their activities] Naukovyi visnyk Natsionalnoi akademii vnutrishnikh sprav - Scientific Bulletin of the National Academy of Internal Affairs, 2, 36-43 [in Ukrainian].

20. Postanova Kabinetu Ministriv Ukrainy "Pro zatverdzhennia Poriadku spryiannia provedenniu hromadskoi ekspertyzy diialnosti orhaniv vykonavchoi vlady" vid 05.11.2008 No 976 [Resolution of the Cabinet of Ministers of Ukraine "On statement of the Order of assistance to carrying out public examination of activity of executive authorities" as 05.11.2008 No 976]. zakon.rada.gov.ua URL : https://zakon.rada.gov.ua/ [in Ukrainian].

21. Vnesky prohramy "U-LEAD $\mathrm{z}$ Yevropoiu" u stvorennia bahatorivnevoi systemy upravlinnia, yaka ye prozoroiu, pidzvitnoiu ta reahuie na potreby hromadian Ukrainy (stanom na serpen 2020 r.). URL : https://donors.decentralization.gov.ua/project/u-lead [in Ukrainian].

22. Stratehichne planuvannia rozvytku obiednanykh terytorialnykh hromad [Strategic planning for the development of united territorial communities]. URL : https://despro.org.ua/social-projects/mistsevistrategiyi-rozvytku-sela/ [in Ukrainian]. 


\title{
REGULATORY AND LEGAL PRINCIPLES OF INFORMATION OPENNESS AND COMMUNICATIVE INTERACTION OF PUBLIC AUTHORITIES WITH PUBLIC REPRESENTATIVES
}

Prylipko Sergii, Doc. Sc. (Pbl Adm.), Assoc. Prof., Acting Head of the Department of Public Administration and Innovation Management of National University of Life and Environmental Sciences of Ukraine, 03041, Kyiv, 15 Heroiv Oborony Str., tel. +380677083679, e-mail: prylipko@nubip.edu.ua, https://orcid.org/0000-0002-6116-328X

\begin{abstract}
The modern concept of public administration requires public authorities to be more sensitive to citizens' requests, involve civil society institutions more widely to the process of making public administration decisions, carry out their activities transparently and openly. Public informing and communicative interaction are the main tools for ensuring openness and transparency of the subiects of power relations. The authorities should be interested in establishing communication in various forms, which will promote to the success of the declared reforms and increase public trust. It is established that the information relations between the subiects of public administration are based on the principles of openness, accessibility, reliability, completeness, legality of receipt, use, distribution of information. At the same time in order to establish two-way communication, the communicative interaction in public administration between representatives of power and the public must meet the principles of transparency, openness, honesty, efficiency, adequacy, partnership, reliability and accountability. In a democratic societv, every citizen has the right to receive full and accurate information about the activities of public authorities, and the latter are obliged to timely and fully provide it, involve the public representatives to the formation and implementation of public policy. Based on the analysis of regulatory and legal support, it is determined that information and communication activities are regulated by certain provisions of the Constitution of Ukraine, laws of Ukraine, resolutions of the Cabinet of Ministers of Ukraine and other regulations. Thev reveal the rights and responsibilities of public authorities to transparently provide information and report on their activities, respond to inquiries, discuss publicly draft regulations, hold public hearings and take into account public opinion. It is established that the best forms of communication are: reception of citizens, meetings, consultations, round tables, seminars, conferences, gatherings, ceremonial events, public hearings, public debates, demonstrations, presentations, exhibitions, briefings, press conferences, press tours, incoming and outgoing correspondence, messages in the media, social networks, on websites.It is noted that the involvement of programs and projects of international technical assistance promotes to the establishment of communicative interaction between public authorities and representatives of civil societv institutions, in particular during the development of communication strategv.
\end{abstract}

Keywords: public administration, regulatory and legal support, information openness, communicative interaction, public authorities, public representatives. 